\title{
Ambiguity of the Position of Directors of State-Owned Enterprises (Persero): Achievements of Profits and Allegations of Corruption
}

\author{
Hasrul Benny Harahap ${ }^{1},{ }^{*}$ Hikmahanto Juwana $^{2}$, Mahmul Siregar ${ }^{3}$ \\ Universitas Sumatera Utara-Indonesia ${ }^{13}$, Universitas Indonesia-Indonesia ${ }^{2}$ \\ Email: hbhlaw92@gmail.com
}

\begin{abstract}
The management of State-Owned Enterprises (SOEs) in Indonesia has special characteristics. While business entities SOEs (Persero) are directed to seek profit in order to increase the national economy. However, venture capital SOEs derived from separated state assets provides space for SOEs (Persero) directors to be blamed for corruption charges. The problem in this research is how the position of directors SOEs (Persero) for business decisions in realizing the goals of this company. This paper is normative legal research using a descriptive analytical method which aim to explain, describe and correlate legal regulations and theories with the problems that occur. The finding shows that the character (SOEs) in Indonesia has internalized the package of state financial regulations in the company management mechanism. Losses SOEs (Persero) are associated with state losses which lead to allegations of corruption to the directors of SOEs (Persero). The guiding rule of business judgment adopted by any company's mechanism are faced with the state financial system with a public dimension, so this principle does not necessarily become an element of defense for directors of SOEs (Persero)for adverse business decisions of (SOEs). The purpose of formation SOEs (Persero) to seek profit and benefit is not optimal, directors of SOEs(Persero) tend to make safeguard on their business decisions, given the allegations of corruption that can be leveled against them if the decision results in losses to state companies.
\end{abstract}

Keywords: SOEs (Persero), business Judgment rule, state losses, corruption.

\section{INTRODUCTION}

Various economic experts' analyses Assume that the state's involvement in the economy is the result of market failure, particularly in macroeconomic problems.[1] In order to achieve national economic development for the benefit of the people, SOEs (Persero)were established in Indonesia. This objective was described in the provisions of Law No 19 of 2003 "On State Enterprises". Article 2(1) ie: 1) support for the development of the national economy in general and the national income in particular; 2) the pursuit of profit 3 ) the organization of public goods in the form of providing quality and appropriate goods and/or services to meet people's needs. and 4) being a pioneer in business activities that the private sector and cooperatives have not been able to carry out.

The phenomenon (SOEs) applies in any economic system. From the many economic systems used, such as market mechanisms, social democracy, and capitalism, making the role of SOEs vary widely in various countries.[2] SOEs in Indonesia play There are two primary roles: as a state corporation seeking profit to boost foreign exchange for the country (agent of business) and as a tool for the government to deliver community services (public service obligation or PSO). This dual role of SOEs is realized by categorizing SOEs as public businesses (Perum) or limited liability firms (Persero).

The management of SOEs applies all the Rules and Principles Applicable to Limited Liability Companies under the Limited Liability Companies Act (Law No. 40 of 2007).[3] Thus, the management of SOEs, apart from referring to the SOEs Law, is also directed towards its management based on the The law of limited liability companies. A limited liability company is a type of firm that exists in the form of a corporation. SOEs (Persero) is directed to gain profits in addition to providie benefits to the community.

The development of an economic organization is not a simple job, business competition in today's changing socio-economic conditions requires that every time there is a review of the existence of an organization. The wheels of organization and economic management should indeed be appreciated professionally in order to increase the effectiveness of activities to achieve 
goals.[4] The business judgment rule principle is internalized in the limited liability company mechanism

blamed for their business decisions, as long as the business decisions are meant for the company's advantage and in compliance with the set method

SOEs are very likely to be strategic organizations to achieve the government's political goals, [5] the establishment of SOEs is directed to realize a strong economy. The SOEs management policy in Indonesia places it in the state financial system, because SOEs capital comes from separated state assets. So that the finances and assets of SOEs are part of state finances. This gives rise to the interpretation that the losses of SOEs (Persero) are associated as state losses, allegations of corruption can be directed at the directors of SOEs (Persero) as decision makers because the directors are in charge of the company's management connected to the responsible organ for the management of the company. As a business entity, SOEs (Persero) apply a state financial system regulated in the state financial regulation package.

Economic policy is a political decision because it affects the distribution of wealth and income in society. The ruling class will determine economic policy and will make decisions from the various alternatives available in solving economic problems. Therefore, the person who becomes the government really determines the direction of economic policy, while the determination of who governs is a political product.[6] Thus the actions of SOEs in managing the state economy be conditional on how technology is incorporated into a state's political economy.

\section{RESEARCH METHODS}

This paper is normative legal research using secondary legal materials, including Documents such as government materials, library books, rules and regulations, scientific articles, and research documents. [7]

\section{FINDING AND ANALYSIS}

\subsection{Special Characteristics of SOEs}

Juridically, the state as a public legal entity and power organization certainly cannot play an active and direct role in business activities which will reduce its function to administer government and public services. Thus, the state as a public entity establishes a civil law entity that carries out economic functions directly, with the aim of achieving current business activities without relying on the state budget, which will also be flexible. Therefore, the state has the legal discretion to form business entities which are autonomous legal entities, so-called SOEs.[8]

One of the goals and objectives of SOEs is the pursuit of profit. Although this goal is flanked by non-profit goals, the concept of pursuing profit basically erases the which provides a defense for the directors of the SOEs not to be easily

image of SOEs as business entities that only carries out the socio-economic mission of the government. However, SOEs psychologically have a role as government partners in carrying out programs related to non-profit economic programs.[9]

SOEs have special characteristics with complex and conflicting objectives, strong political intervention, and lack of transparency, causing SOEs to have unique governance compared to the private sector. From the state side, there are challenges in the form of many interests from various state agencies/Ministries to intervene in the management of SOEs. From the side There are issues in the form of the Supervisory Board, their weak authority to oversee the board of directors and their position as bureaucratic officials who have limited time to supervise SOEs. Meanwhile, on the management side, SOEs managers often face challenges in the form of a poor remuneration system and low management discipline.[10]

The existence of SOEs that often seem ambivalent or paradoxical does have its own charm for a debate. On the other hand, various parties like to exemplify SOEs as business entities that are difficult to make a profit. However, there are no less experts who express the added value of SOEs. For example, the issue of proximity to bureaucrats and government elites. As the majority shareholder, of course, the government has the authority to take SOEs steps at the corporate level, but for operational aspects that often require accuracy and speed in making decisions, autonomy or empowerment should be given to the related SOEs management. [11]

The reality in Indonesia still shows that the burden of SOEs is too heavy in carrying out their public roles, so that SOEs often show support for government program activities rather than showing their ability to handle corporate accountability and profitability processes. The inability of SOEs to realize the probability will have an unfavorable impact on the state as its shareholder because of the possibility that the state will bear the loss.

SOEs sometimes become the authority on behalf of the state to carry out certain policies that do not generate profits, and impose subsidies that must be borne by the state budget. In understanding this situation, there needs to be accountability for the delegation of state public duties to SOEs which require a comprehensive SOE accountability system and are closely related to conducive state economic policies.[12] With his utilitarianism philosophy, Jeremy Bentam believes in "the greatest enjoyment for the greatest number." This point of view contends that adopting ethical policies based on the greatest benefit to the people or maximizing benefits to increase the prosperity, well-being that makes an happiness to the society. [13]

SOEs are the personification of the state in their form as civil legal entities, but are aimed at supporting the 
realization of economic activity for mutual prosperity. In this concept, SOEs must be prepared to face the possibility of experiencing losses because the pursuit of profit is not the main orientation. [14]Because of their role, SOEs have the privilege of carrying out certain business activities, which raises the question of whether SOEs are running a civil business or are carrying out public services that are the duty of the state? [15]

\subsection{Between the Mechanism of the Company and the State Financial System}

The business judgment rule principle that is internalized in the Limited Liability Company Law is a positive thing for aid in the growth of Indonesia's business climate. In the provisions of Paragraph (5) of Article 97 on the Limited Liability Company Law, a director is released from responsibility for company losses if he can prove: 1) The losses that arise are not as a result of his carelessness or neglect; 2) The Director carries by the management in good sincerity and with care;3) Management is carried out for the interests and the company's goals; 4) The director does not has any conflicts of interest; and 5) Have taken steps to prevent losses.

The Directors of a company is given high trust by the company to manage a company. In this case, the directors must have high standards of integrity and loyalty, appear and operate in the company's best interests, in a bona fides manner..[16] Regarding the existence of SOEs as a state company, apart from seeking profit it is also intended for the benefit of the community, the integrity and loyalty of the directors should be the criteria that must be prioritized in achieving this goal.

The ability of the board of directors is also required in interpreting and implementing the company's policies well for the benefit of the firm, the advancement of the company, the increase in the value of the company's shares, and the generation of income for the company, shareholders and stakeholders. Based on the authority available to him (proper purposes), the board of directors capable to articulate their responsibilities correctly, so that the organization stays on the right or proper track As a result, the board of directors capable to prohibit the corporation from engaging in criminal activities that are counter to rules and the public interest, as well as agreements established with other governmental organs, shareholders, and stakeholders..[17]

Therefore, a director must act carefully in carrying out his duties (duty of care)..[18] A director may not take advantage of himself for the benefit of the firm while carrying out his obligations. [19] Infringement on these two fiduciary duty standards may result in the director being held personally liable for his acts. both to shareholders and to third-party stakeholders. [20]

The position of the directors in making business decisions as well as a risk taker aiming to seek profit where the board of directors as a company organ in making business decisions is often speculative with a tendency to incur losses that where accountability standards come into play, allowing you to observe which business choices are made in line with protocols for the advantage of the company and which business decisions are made for the profit of the individual. director himself. The principle of business judgment rule is a means to be able to provide standards that can measure the actions taken by SOEs (Persero) directors.

SOEs are characterized as commercial enterprises in which the state owns all or most of the capital through direct support derived from distinct state assets..[21] Separation of government assets requires SOEs to be autonomous legal entities with distinct obligations and assets from their owners (the State). In Indonesia, there are various laws and regulations that classify SOEs as public enterprises and part of the state budget. Even if they have been split, Law No. 17 of 2003 concerning State Finance and Law No. 1 of 2004 about the State Treasury reaffirm that the wealth of SOEs is part of the wealth or state finances. As a result of the two rules, the procedures for using SOE assets are carried out in compliance with the procedures for using state funds.

The State Finance Law along with other laws which have the principle that 'SOE finances are state finances', assume that the declare (from the cases represented as the government) will always act as a public legal entity, even when holding dominant shares in SOEs. The consequence of this principle is that all SOE's assets or company assets will always be considered as state assets. The legal consequence of such a principle is that SOEs can easily come into contact with Amendments to Law No. 31 of 1999 Concerning the Eradication of Corruption Crimes (Law No. 20 of 2001) (Corruption Act). Considering that one of the elements of corruption in the explanation of the Corruption Act is "State financial losses" do exist. Meanwhile, according to the AntiCorruption Law, one of the state's finances is "rights and duties resulting from being under the ownership, administration, and accountability of SOEs or Regional Owned Enterprises (BUMD), foundations, and legal entities"

The concept of state assets separated into SOEs as corporate capital has in fact been transformed into wealth or assets from SOEs. The government is a representation of the state as a subject of public law, by separating wealth in the State Budget to be used as capital for SOEs, at that time public immunity from the state is lost and its legal relationship with state finances has been turned into shares. [22]At the same time, the role of the state (government) turned into a private legal subject as a shareholder who was fully subject to the provisions of private law (civil) namely, the Limited Liability Company Law. The state as a shareholder should not be responsible for contracts and transactions which carried out by SOEs even if they suffer losses, in accordance with the principle of limited liability outlined in Article 3 paragraph (1) of the Limited Liability Company Law..[23] The Provisions for criminal acts of corruption 
should not be applied in the management of SOEs, if the SOEs company suffers losses due to business decisions taken by the directors.

These ideas of value expectations and attitudes toward law and legal institutions that partly in the public domain are by no means a universally accepted definition, but nevertheless they are one useful way of describing measurable phenomena..[24] In determining economic policy it is not the interests of the nation-state that are the most dominant. This situation shows that the law is indeed trying to tame the power, but in certain contexts that power is able to make the law very wild. This phenomenon is part of the dialectical process of socio-economic life that has been going on for a long time, and it seems difficult to predict when it will end.[25]

The legal challenge that is still faced by every SOEs in Indonesia is actually the dualism of groups of laws and regulations that have different perspectives in determining state assets in SOES. The misalignment of understanding the laws and regulations regarding the true concept of state assets, has created chaos in the logic of legal thought and has a serious impact on the functioning of State-Owned Enterprises, which in turn has an impact on the micro and macro economy, including the investment climate for SOEs (Persero) in Indonesia. Business Decisions of the Board of Directors of SOEs (Persero): Concerns over Allegations of Corruption

\subsection{Business Decisions of The Directors of SOEs: Concerns Over Allegations Of Corruption}

SOEs face many major problems and challenges, for example, most SOEs suffer significant losses due to not having the ability to compete in business competition in both domestic and international markets. This situation becomes a burden on state finances because SOEs are not managed with good business management principles as a result of government intervention that is too large or dominant in the company's operations.[26]

The establishment of SOEs in Indonesia is as a private entity,[27] considering its activity is to run a state company. However, the state financial regulation policy package justifies its existence as part of a public entity because the capital for its formation comes from separated state assets. This policy has an impact on the performance of SOEs that are not optimal, given the establishment of SOEs to contribute to development and benefit the community.

SOEs are relied upon as entities with a profit-making function and supporting tools for implementing national development, both functions clearly cannot be realized if SOEs organs are limited in their scope of movement in making business decisions by the State Finance legislation group. These two functions cannot be carried out optimally if the distinction between the roles and positions of the government is not limited. Without these differences in roles or positions, a conducive legal system that provides the greatest support for achieving the Pareto optimum level for economic development and good governance and good corporate governance will be difficult to achieve.[28] The principle of business judgment rule adopted in the Limited Companies Law cannot necessarily be used as a defense for the directors of SOEs if the state company suffers losses as a result of the business decisions taken.

In practice, there have been many directors and structural officers at SOEs who have become patients due to corruption cases related to the neglect of the application of the business judgment rule. This condition causes many of the directors and structural officers at SOEs who are convicts to be unable to defend themselves optimally because they cannot prove that they have implemented the SOEs business judgment rule principle properly and correctly, so they have to bear the consequences as convicts, not even a few have to pay. compensation and confiscated assets for the state.[29] This situation occurred in former Directors of PT Merpati (Persero), former President Director of PT. PLN (Persero), and former President Director and Director of PT. Pertamina (Persero). This phenomenon becomes a dilemma for SOEs directors in carrying out corporate actions. As a result, many SOEs directors do not dare to make business decisions which contain risks and tend to make it safeguard on their business decision. This situation has an impact on the main objective of establishing SOEs which are actually the locomotive of the national economy.

Efficient economic conditions will be achieved if a situation of no person can be made better off without making someone worse-off. [30]This is what so called fair, which is not only the main objective of the political field, but is also the goal of law. With a justice-centered approach in political economy, the state plays an important role in upholding justice,[31] Moreover, the economic sector has a direct impact on the wider community. Difficulties in such circumstances will actually lead to difficulties for the state to obtain revenue allocation or income from SOEs contributions. In the end, minimal income will have an impact on the implementation of development that is not optimal which leads to the inhibition of the realization of the ideals of the welfare state.

Legal positions are always involved in negotiations over time and place, so it is almost impossible to imagine such interactions in the form of images on paper which tend to give a static impression and do not show the inherent dynamism and instability in legal processes.[32] The implementation of the company law and the package of state financial regulations as protection for the management of SOEs should provide the right position as stated in Article 33 of the 1945 Constitution as the philosophical basics for its formation, because law is one of the various systems that are meaningful for economic development. The rule of law is an important issue that 
has a broad impact on reforming a country's economic system.

\section{CONCLUSION}

SOEs (Persero) are state companies that were formed to provide profit to the state and contribute to the growth

company mechanism that adheres to the business judgment rule principle, but the state financial regulation package that adheres to the SOEs financial principle is that state finances have obscured the business judgment rule principle. Directors of SOEs can be blamed for allegations of corruption if their business decisions lead to losses for state companies, because SOEs losses can be associated with state losses.

The contrast between the two principles in the private and public domains, has an impact on the ambiguity of the position of the SOEs directors, on the one hand they are given the task of seeking corporate profits but on the other hand they are faced with allegations of corruption if the business decisions taken result in losses for the company. This situation is a concern for SOEs directors

\section{REFERENCES}

[1] Lubis, T. M,1987, Hukum dan Ekonomi, Jakarta: Sinar Harapan, p. 59

[2] Estrin,S,The Internationalization of State Owned Enterprises: The Impact of Political Economy and Institutions, Departement of Management London School of Economics. p. 3

[3] Article 11 of Law No. 19 of 2003 concerning StateOwned Enterprises

[4] Priambodo,D. S,2004, Perjalanan Panjang dan Berliku: Refleksi Bumn 1993-2003,Sebuah Catatan tentang Peristiwa, Pandangan dan Renungan dalam Satu Dasawarsa, Yogyakarta: Kreasi Media Pressindo, p. 20

[5] Buckley P.J., Clegg J., Cross A., Liu X., Voss H. \& Zheng P.. The determinants of Chinese outward FDI. Journal of International Business Studies 2007. p. 499

[6] Surbakti, R,1991, Memahami Ilmu Politik, Jakarta: Gramedia Widyasarana, hlm. 205-210

[7] Soekanto S \&Mamudji S, 2011, Penelitian Hukum Normatif, Suatu Tinjauan Singkat, Jakarta: Raja Grafindo Persada, p. 12

[8] Simatupang,D. P. N,2011, Paradoks Rasionalitas, Perluasan Ruang Lingkup Keuangan Negara dan Implikasinya terhadap Kinerja Keuangan Pemerintah, Badan Penerbit FHUI, Jakarta, p. 235

[9] Kamerman,S. B\&Kahn,A. J. Privatization and the Welfare State, Pricenton, t.t, p. 113

[10] Pranoto,T,2011, Faktor Faktor yang Mempengaruhi Keberhasilan Privatisasi BUMN: Komparasi Indonesia-Malaysia, Lembaga Management FE-UI. for the national economy. The position of SOEs (Persero) as business entities is managed based on a limited liability

to dare to make decisions, so SOEs directors tend to make it safe in high-risk policies. If SOEs are currently in a state of stagnation as a business entity, it is necessary to review the regulatory framework that is the reference for the management of the state company.

\section{ACKNOWLEDGMENT}

The author would like to thank you profusely for all the help that has been given, either directly or indirectly during the preparation of this research complete Properly. In particular gratitudes that are due to Doctoral Program in Law, University of North Sumatra, which has supported the author, so that this research can be published in international journals.

Paper presented at FE-UI Research Day, December 13 p. $10-11$

[11] Priambodo, D. S,Op.Cit, p. 37-38

[12] Simatupang,D. P. N,Op.Cit, p. 243

[13] Bentham,J,2000, An Introduction to the Principle of Moral and Legislation,Batoche Book, Kitchener, p. 6

[14] Anoraga, P, 1994, BUMN, Swasta dan Koperasi Tiga Pelaku Utama Semarang: Pustaka Jaya, p. 21-22.

[15] Donahue, J. D. 1989,The Privatization Decision: Public End, Private Means, USA: Basicbooks, p. 45.

[16] Khairandy, R, 2009,Perseroan Terbatas: Doktrin, Peraturan Perundang-undangan, dan Yurisprudensi,Yogyakarta: Kreasi Total Media, p. 207

[17] I b i d

[18] Keenan,D\&Biscare, J, 1991, Smith \& Keenan's Company Law For Students, Financial Times, Pitman Publishing, p. 317

[19] Seligman, J, 1995, CorporationsCases and Materials, Little Brown and Company Boston New York Toronto London, p. 415

[20] Nasution, B, Tanggung Jawab Direksi dan Komisaris Dalam Pengelolaan Perseroan Terbatas Bank, paper presented at the Seminar Sehari "Tanggung Jawab Pengurus Bank Dalam Penegakan dan Penanganan Penyimpangan di Bidang Perbankan menurut UUT dan Undang-Undang Perbankan"' Surabaya, February 21, 2008,p. 10 .

[21] Article 1 number (1) of Law no. 19 of 2003 concerning State-Owned Enterprises.

[22] Atmadja, A. P. S, 2009, Keuangan Publik dalam Perspektif Hukum: Teori, Praktik, dan Kritik, Jakarta: Rajawali Pers,p. 101 
[23] Harahap, M. Y, 2015, Hukum Perseroan Terbatas, Jakarta: Sinar Grafika, p. 258.

[24] Cruz, P. d, 2016, Perbandingan Sistem Hukum: Common Law, Civil Law, and Socialist Law, Bandung: Nusa Media, Cet. VII, p. 7

[25] Husein, Y, 2003,Rahasia Bank: Privasi Versus Kepentingan Umum, Jakarta: Program Pascasarjana Fakultas Hukum Universitas Indonesia, p. 72-73

[26] Diah,M. M. 2003, Restrukturisasi BUMN di Indonesia, Jakarta: Literata Lintas Media, p. 11

[27] Hartini, Rahayu,2017, BUMN Persero: Konsep Keuangan Negara dan Hukum Kepailitan Indonesia, Malang: Setara Pers, p. 33
[28] Atmadja, A. P. S, Op.Cit, p. 109.

[29] Zulmawan, Wawan, 2019Business Judgment Rule $B U M N$,Jakarta: Jala Permata Aksara, p. 52

[30] Rachbini, D. J. 2002,Ekonomi di Era Transisi Demokrasi, Jakarta: Ghalia, p. 4

[31] Caporaso, J. A, 1992, Theorities of Political Economy, Cambridge: Cambridge University Press, p. 221

[32] Menski, W, 2012, Perbandingan Hukum dalam Konteks Global: Sistem Eropa, Asia, dan Afrika, Bandung: Nusa Media, p. 795. 